JOSING: Journal of Nursing and Health

Volume 2, Nomor 1, Desember 2021

e-ISSN: $2745-7877$

p-ISSN: 2746-0851

DOI: https://doi.org/10.31539/josing.v2i1.3022

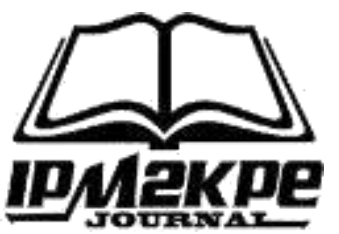

\title{
CARDIOVASCULAR PATIENT'S ANXIETY IN THE TIME OF THE COVID-19 PANDEMIC
}

\author{
Jasper Suinite Pole ${ }^{1}$, Juli Andri ${ }^{2}$, Padila ${ }^{3}$ \\ Jasper Suinite Pole Port Moresby General Hospital, Papua New Guinea ${ }^{1}$ \\ University of Muhammadiyah Bengkulu ${ }^{2,3}$ \\ juliandri@umb.ac.id ${ }^{2}$
}

\begin{abstract}
This study aims to determine the level of anxiety of patients with cardiovascular disorders during the COVID-19 pandemic. The type of research used in this research is quantitative research with a cross-sectional approach. The results showed that the level of anxiety of respondents who were included in the standard/not anxious category was four respondents (5.4\%), mild anxiety was 27 respondents (36.5\%), moderate anxiety was 33 respondents (44.6\%), and anxious weight as many as ten respondents (13.5\%). In conclusion, the anxiety level of patients with cardiovascular disorders during the COVID-19 pandemic was in the moderate anxiety category.
\end{abstract}

Keywords: Anxiety, Cardiovascular, COVID-19

\section{INTRODUCTION}

The start of 2020 has been a shocking year for everyone worldwide, as the Corona Virus (COVID-19) pandemic has caused panic everywhere. Hundreds of thousands if not millions of people have been infected, and thousands have died. According to data from the World Health Organization (2020), as many as 106 countries in the world have been exposed to the coronavirus, with 2,804,796 confirmed cases and 193,710 deaths due to the coronavirus. Indonesia is no exception, as one of the countries that have felt the impact of the spread of the new coronavirus (Sharma, 2020).

COVID-19 is a new type of virus discovered in 2019 and has never been found to attack humans before (WHO, 2020; Zulva, 2019). COVID-19 is an infectious disease caused by Severe Acute Respiratory Syndrome Coronavirus 2 (Severe Acute Respiratory Syndrome Coronavirus 2 or SARS-CoV02) (Setiawan, 2020). WHO declared the coronavirus a pandemic on March 11, 2020, and the virus is spreading very fast (Moana, 2020). The status of a global pandemic or epidemic indicates that the spread of COVID-19 is swift.

The government has made various prevention efforts to overcome the spread of this virus rather than spreading quickly, such as working from home (WFH), social distancing, PSBB, etc. (Tursina, 2020). In addition, the public has been given education about the application of a healthy lifestyle (Suprabowo, 2020). Provide education about healthy lifestyles, such as washing hands with soap as often as possible, using masks when leaving the house, and keeping a distance (Machendrawaty et al., 2020; Mardiiana \& Darmalaksana, 2020; Masrul et al., 2020; Pratiwi, 2020).

Current conditions make people physically and psychologically unprepared to respond (Sabir \& Phil, 2016). Wang et al., (2020) also explained that the impact of the COVID-19 pandemic had caused many losses, such as physical barriers, economic 
inequality, social inequality, and mental disorders. When infected with this coronavirus, the psychological condition experienced by the community will feel anxious (Fitria et al., 2020). Huang et al. (2020) explained that mental disorders during the COVID-19 pandemic were anxiety, fear, stress, depression, panic, sadness, depression, anger, and denial.

Anxiety about heart disease will ultimately affect treatment plans because anxiety will reduce the ability to adapt to the effects of the disease (Aburuz, 2018; Mujiono et al., 2020). Excessive anxiety can cause the immune system to decrease, so the risk of contracting this virus will be higher. There is much information about patients dying from COVID-19 with congenital diseases. This should be a particular concern from all walks of life, especially those with a history of systemic disorders and other diseases. Anxiety is an emotional state that causes discomfort, a vague experience, accompanied by helplessness and uncertainty caused by things that are not yet clear. (Annisa \& Ifdil, 2016).

The COVID-19 pandemic is one of the most dangerous spreads of viruses for the community because of its rapid spread. During this pandemic, everyone will experience anxiety, including people with cardiovascular disorders. People with cardiovascular disorders are at risk for anxiety and depression, which will affect the healing process of cardiovascular disease. Therefore, this study wanted to see how people with cardiovascular disorders during the pandemic had their level of anxiety. When a person feels anxious, the body will react by putting excess pressure on the heart so that the heart's work is not optimal.

Previous research on anxiety during the COVID-19 pandemic has been carried out, such as anxiety in adolescents. However, this study focuses on individuals with cardiovascular system disorders. In Bengkulu, there has not been much research done on the anxiety level of cardiovascular patients during the COVID-19 pandemic.

\section{RESEARCH METHOD}

The type of research used in this research is quantitative research with a crosssectional approach. This research will be conducted in the working area of the Telaga Dewa Health Center, Bengkulu City. This research was conducted from March to April 2021. The population in this study were all patients suffering from cardiovascular disorders who live in the working area of the Telaga Dewa Health Center, Bengkulu City, amounting to 89 people. The sampling technique used was the total sampling technique, with the number of samples being 89 people.

The instrument used in data collection in this study was the ZSAR-S (Zung Self Anxiety Rating-Scale) questionnaire. To determine the anxiety level of patients with cardiovascular disorders, the researcher used an instrument in a questionnaire. The researcher used the Zung Self-Rating Anxiety Scale (SAS/SRAS) questionnaire. The Zung Self-Rating Anxiety Scale is an anxiety assessment designed by William WK Zung, developed based on anxiety symptoms in the Diagnostic and Statistical Manual of Mental Disorders (DSM-II). The Zung Self-Rating Anxiety Scale has 20 questions consisting of 15 Unfavorable questions and 5 Favorable questions. Categories of anxiety levels include; Normal/not anxious: Score 20-44; Mild anxiety: Score 45-59; Moderate anxiety: Score 60-74; Severe anxiety: Score 75-80. 


\section{RESULTS}

Table. 1

Frequency Distribution of Respondents

By Gender

\begin{tabular}{|c|c|c|c|}
\hline Number & Anxiety Level & Frequency & Percentage $\%$ \\
\hline 1 & Man & 42 & 56,8 \\
\hline 2 & Woman & 32 & 43,2 \\
\hline & Total & 74 & 100 \\
\hline
\end{tabular}

Based on table 1 shows that most of the respondents are male, namely 42 respondents (56.8).

Table. 2

Anxiety Levels of Patients with Cardiovascular Disorders During the COVID-19 Pandemic

\begin{tabular}{llcc}
\hline Number & Anxiety Levels & Frequency & Percentage \% \\
\hline 1 & Normal & 4 & 5,4 \\
2 & Mild Anxiety & 27 & 36,5 \\
3 & Moderate Anxiety & 33 & 44,6 \\
4 & Heavy Anxiety & 10 & 13,5 \\
\hline & Total & 74 & 100 \\
\hline
\end{tabular}

Based on table 2 shows that most of the anxiety levels of patients with cardiovascular disorders during the COVID-19 pandemic were in the moderate anxiety category, with as many as 33 respondents $(44.6 \%)$.

\section{DISCUSSION}

The results showed that most of the anxiety levels of patients with cardiovascular disorders during the COVID-19 pandemic were in the category of moderate anxiety. COVID-19 has become an epidemic, causing mental health problems such as stress, anxiety, depressive symptoms, insomnia, rejection, anger, and fear (Torales et al., 2020). The coronavirus poses a threat to society and is, therefore, a source of anxiety. According to the results of the study, 2,540 people (35.1\%) suffered from a generalized anxiety disorder, including 1,192 men (47\%) and 1,348 women (53\%) (Huang \& Zhao, 2020). Research conducted in Hubei, China, showed that 62 people (0.9) had experienced severe anxiety, 196 people $(2.7 \%)$ had moderate anxiety, and 1,518 $(21.3 \%)$ experienced mild anxiety (Cao et al., 2020).

According to research conducted by Huang \& Zhao (2020), The overall prevalence of generalized anxiety disorder (GAD), depressive symptoms, and sleep quality in general patients was $35.1 \%, 20.1 \%$, and $18.2 \%$, respectively. (Amirullah \& Kartinah, 2020). Many factors cause anxiety, and knowledge is one of them. Knowledge is the basis of one's actions, so it will stimulate someone to do something. Knowledge can be obtained from various sources, one of which is parents (Utami, 2019). Anxiety can arise from information overload or negative, such as increased transmission and death. Therefore, the community needs health education to balance the information obtained (Supriyadi \& Setyorini, 2020). 
Anxiety is a natural feeling that occurs in humans because people will realize and remind them of dangerous and dangerous situations when they feel anxious. However, when regular and controlled anxiety turns into persistent and uncontrollable anxiety, this anxiety will interfere with daily activities (Dewi \& Fauziah, 2018).

Anxiety is a critical evaluation parameter for patients with heart disease. It should be treated because anxiety is often accompanied by physical symptoms such as chest pain that bothers the patient. Anxiety can also cause cardiovascular system responses such as palpitations, decreased blood pressure, palpitations, decreased pulse rate, and a feeling of fainting. In addition, psychological symptoms can also worsen heart conditions (Hastuti \& Mulyani, 2019; Tobing \& Wulandari, 2021).

The level of anxiety felt by each individual is different, influenced by how the individual adjusts to and copes with situations that trigger anxiety (Anissa et al., 2018). Anxiety often arises in individuals when faced with unpleasant situations (Suryaatmaja \& Wulandari, 2020).

For people with heart disease who experience anxiety can cause blood vessel spasms. This situation causes a myocardial infarction called a heart attack, thus affecting healing (Tobing \& Wulandari, 2021). Conditions that trigger a person's anxiety can lead to an increased risk of fatal heart disease, including hyperventilation that occurs during an acute attack that can cause coronary spasm, arrhythmias, and can lead to ventricular failure. This can affect the cardiovascular system, manifesting in palpitations and shortness of breath (Hajiri et al., 2019).

Anxiety about heart disease will ultimately affect treatment plans because anxiety will reduce the ability to adapt to the effects of the disease (Aburuz, 2018; Mujiono et al., 2020). Excessive anxiety can cause a decrease in body resistance, so the risk of contracting this virus will be higher, especially since there is much information that says that congenital diseases accompany patients who die from COVID-19. This should be a particular concern for all levels of society, especially those who have a history of diseases such as cardiovascular system disorders and other diseases. Anxiety is an emotional condition that causes discomfort in a person and is a vague experience accompanied by feelings of helplessness and uncertainty caused by something not yet clear (Anissa et al., 2018).

\section{CONCLUSION}

The anxiety level of patients with cardiovascular disorders during the COVID-19 pandemic in the Telaga Dewa Health Center work area, Bengkulu City, was in the category of moderate anxiety.

\section{SUGGESTIONS}

Suggestions from this study are expected that health workers can provide more optimal services and treatment for patients with cardiovascular disorders. For further researchers, it is hoped that they can conduct research that focuses on nonpharmacological interventions given to patients with cardiovascular disorders in overcoming the anxiety they feel during the COVID-19 pandemic. 


\section{REFERENCES}

Aburuz, M. E. (2018). Anxiety and Depression Predicted Quality of Life among Patients with Heart Failure. Journal of Multidisciplinary Healthcare, 11, 367373. https://doi.org/10.2147/JMDH.S170327

Amirullah, A. K., \& Kartinah, K. (2020). Penanganan Kecemasan Pasien Survivor COVID-19 Intensive Care Unit: Literature Review. Seminar Nasional Keperawatan Universitas Muhammadiyah Surakarta (SEMNASKEP), 8-15. https://publikasiilmiah.ums.ac.id/handle/11617/12261

Anissa, L. M., Suryani, S., \& Mirwanti, R. (2018). Tingkat Kecemasan Mahasiswa Keperawatan dalam Menghadapi Ujian Berbasis Computer Based Test. Medisains, 16(2), 67. https://doi.org/10.30595/medisains.v16i2.2522

Annisa, D. F., \& Ifdil, I. (2016). Konsep Kecemasan (Anxiety) pada Lanjut Usia (Lansia). Konselor, 5(2), 93. https://doi.org/10.24036/02016526480-0-00

Cao, W., Fang, Z., Hou, G., Han, M., Xu, X., Dong, J., \& Zheng, J. (2020). The Psychological Impact of the COVID-19 Epidemic on College Students in China. Psychiatry Research, 287(112934), 1-5. https://doi.org/10.1016/j.psychres.2020.112934

Dewi, I. P., \& Fauziah, D. (2018). Pengaruh Terapi Seft terhadap Penurunan Tingkat Kecemasan pada Para Pengguna Napza. Jurnal Keperawatan Muhammadiyah, 2(2), 135-150. https://doi.org/10.30651/jkm.v2i2.1094

Fitria, L., Neviyarni, N., \& Karneli, Y. (2020). Cognitive Behavior Therapy Counseling untuk Mengatasi Anxiety dalam Masa Pandemi COVID-19. Al-Irsyad: Jurnal Pendidikan Dan Konseling, 10(1), 23-29. http://jurnal.uinsu.ac.id/index.php/alirsyad/article/viewFile/7651/3538

Hajiri, F., Pujiastuti, S. E., \& Siswanto, J. (2019). Terapi Murottal dengan Akupresur terhadap Tingkat Kecemasan dan Kadar Gula Darah pada Pasien dengan Penyakit Jantung Koroner. Jurnal Keperawatan Silampari, 2(2), 146-159. https://doi.org/10.31539/jks.v2i2.507

Hastuti, Y. D., \& Mulyani, E. D. (2019). Kecemasan Pasien dengan Penyakit Jantung Koroner Paska Percutaneous Coronary Intervention. Jurnal Perawat Indonesia, 3(3), 167. https://doi.org/10.32584/jpi.v3i3.427

Huang, C., Wang, Y., Li, X., Ren, L., Zhao, J., Hu, Y., Zhang, L., Fan, G., Xu, J., Gu, X., Cheng, Z., Yu, T., Xia, J., Wei, Y., Wu, W., Xie, X., Yin, W., Li, H., Liu, M., \& Cao, B. (2020). Clinical Features of Patients Infected with 2019 Novel Coronavirus in Wuhan, China. The Lancet, 395(10223), 497-506. https://doi.org/10.1016/S0140-6736(20)30183-5

Huang, Y., \& Zhao, N. (2020). Generalized Anxiety Disorder, Depressive Symptoms, and Sleep Quality during COVID-19 Outbreak in China: A Web-Based CrossSectional Survey. Psychiatry Research, 288(112954), 1-6. https://doi.org/10.1016/j.psychres.2020.112954

Machendrawaty, N., Yuliani, Y., Setiawan, A. I., \& Yuningsih, Y. (2020). Optimalisasi Fungsi Mesjid di Tengah Pandemic Covid 19: Telaah Syar'i, Regulasi dan Aplikasi. UIN Sunan Gunung, 19, 1-11. http://digilib.uinsgd.ac.id/30900/

Mardiiana, D., \& Darmalaksana, W. (2020). Relevansi Syahid Ma'nawi dengan Peristiwa Pandemic COVID-19: Studi Matan Pendekatan Ma'anil Hadis Dede. Journal of Chemical Information and Modeling, 4(1), 12-19. https://www.perspektif.uinsgd.ac.id/index.php/JP/article/view/58 
Masrul, M., Tasnim, J. S., Sulaiman, C. P. D. O. K., Purnomo, A., Febrianty, D. H. S., Purba, D. W., \& Ramadhani, Y. (2020). Pandemik COVID-19: Persoalan dan Refleksi di Indonesia. In Yayasan Kita Menulis. https://www.researchgate.net/profile/Daud-Daud-2/publication/341218892

Moana, N. (2020). Konsep Isolasi dalam Jaringan Sosial untuk Meminimalisasi Efek Contagious (Kasus Penyebaran Virus Corona di Indonesia). Jurnal Sosial Humaniora Terapan, 2(2), 117-125. https://doi.org/10.7454/jsht.v2i2.86

Mujiono, A., Sobirin, M. A., \& Ropyanto, C. B. (2020). Peran Yoga dalam Menurunkan Kecemasan pada Pasien Jantung. In Journal of TSCNers, 5(1). http://ejournal.annurpurwodadi.ac.id/index.php/TSCNers

Pratiwi, A. D. (2020). Gambaran Penggunaan Masker di Masa Pandemi COVID-19 Pada Masyarakat di Kabupaten Muna. Prosiding Nasional COVID-19, 52-57. https://www.mendeley.com/catalogue/ee828287-9e25-37b2-aeb8a92b94ed347c/?utm_source=desktop\&utm_medium $=1.19 .4 \& u t m \_c a m p a i g n=o p e$ n_catalog\&userDocumentId=\%7Bb93b070a-115c-4260-854c-e57f42c47e86\%7D

Sabir, A., \& Phil, M. (2016). Gambaran Umum Persepsi Masyarakat terhadap Bencana di Indonesia. Jurnal Ilmu Ekonomi dan Sosial, 5(3), 304-326. https://media.neliti.com/media/publications/237547-gambaran-umum-persepsimasyarakat-terhad-501404e6.pdf

Setiawan, A. R. (2020). Lembar Kegiatan Literasi Saintifik untuk Pembelajaran Jarak Jauh Topik Penyakit Coronavirus 2019 (COVID-19). Edukatif: Jurnal Ilmu Pendidikan, 2(1), 28-37. https://doi.org/10.31004/edukatif.v2i1.80

Sharma, A. K. (2020). Novel Coronavirus Disease (COVID-19). Resonance, 25(5), 647-668. https://doi.org/10.1007/s12045-020-0981-3

Suprabowo, G. Y. A. (2020). Memaknai Hospitalitas di Era New Normal: Sebuah Tinjauan Teologis Lukas 10:25-37. Harvester: Jurnal Teologi dan Kepemimpinan Kristen, 5(1), 43-58. https://doi.org/10.52104/harvester.v5i1.29

Supriyadi, S., \& Setyorini, A. (2020). Pengaruh Pendidikan Kesehatan tentang Pencegahan COVID-19 terhadap Kecemasan pada Masyarakat di Yogyakata. Jurnal Keperawatan, 12(4), 767-776. http://www.journal.stikeskendal.ac.id/index.php/Keperawatan/article/download/99 $3 / 591$

Suryaatmaja, D. J. C., \& Wulandari, I. S. M. (2020). Hubungan Tingkat Kecemasan terhadap Sikap Remaja akibat Pandemik COVID-19. Malahayati Nursing Journal, 2(4), 820-829. https://doi.org/10.33024/manuju.v2i4.3131

Tobing, C. P. R. L., \& Wulandari, I. S. M. (2021). Tingkat Kecemasan bagi Lansia yang Memiliki Penyakit Penyerta Ditengah Situasi Pandemik Covid - 19 di Kecamatan Parongpong, Bandung Barat. Community of Publishing In Nursing(COPING), 9(2), 135-142. https://ojs.unud.ac.id/index.php/coping/article/view/71693/39393

Torales, J., O'Higgins, M., Castaldelli-Maia, J. M., \& Ventriglio, A. (2020). The Outbreak of COVID-19 Coronavirus and Its Impact on Global Mental Health. In International Journal of Social Psychiatry, 66(4), 317-320. https://doi.org/10.1177/0020764020915212

Tursina, A. (2020). COVID-19 dan Lansia (Pusat Pene). https://lppm.unisba.ac.id/pusatpenerbitan-unisba-p2u/ 
Utami, Y. A. P. (2019). Hubungan Tingkat Pengetahuan dengan Tingkat Kecemasan Remaja dalam Menghadapi Menarche pada Siswi Kelas V dan VI di SD Negeri 1 Ceper Klaten. Jurnal Keperawatan, 4(1), 1-12. http://digilib.unmuhjember.ac.id/download.php?id=3456

Wang, Z., Qiang, W., \& Ke, H. (2020). A Handbook of 2019-nCoV Pneumonia Control and Prevention. In Hubei Science and technology press. http://fpmpam.org/files/Handbook_2019nCoV.pdf

WHO. (2020). Report of the WHO-China Joint Mission on Coronavirus Disease 2019 (COVID-19). The WHO-China Joint Mission on Coronavirus Disease 2019, 2019(February), 16-24. https://www.who.int/docs/defaultsource/coronaviruse/who-china-joint-mission-on-COVID-19-final-report.pdf

Zulva, T. N. I. (2019). COVID-19 dan Kecenderungan Psikosomatis. Journal of Chemical Information and Modeling, 53(9), 1689-1699. http://dx.doi.org/10.33087/jiubj.v21i1.1328 